\title{
Geographical names to support monitoring of the regional dynamic in Magelang, Central Java, Indonesia
}

\author{
Ari Cahyono $^{\mathrm{a}, \mathrm{b}} *$, Rossaydiana Apriadna ${ }^{\mathrm{c}}$, Yuniarsita Setyo Wulandari ${ }^{\mathrm{c}}$, Siti Martha Uly Br S. ${ }^{\mathrm{d}}$ \\ ${ }^{a}$ Faculty of Geography, Universitas Gadjah Mada, aricahyono@ugm.ac.id \\ ${ }^{b}$ Doctoral Student on Geography, Faculty of Geography, Universitas Gadjah Mada \\ ${ }^{c}$ Alumni of the undergraduate Cartography and Remote Sensing Study Program, Faculty of Geography, Universitas Gadjah Mada \\ ${ }^{d}$ The undergraduate student of Cartography and Remote Sensing Study Program, Faculty of Geography, Universitas Gadjah Mada \\ * Corresponding author
}

\begin{abstract}
Maps is a valuable tool for the geographer to do geographical research. One of the maps' layer is geographical names. Geographical names belong to the cultural heritage and could help identify the development of human's civilization. The boundaries that spread throughout a region have the characteristic of constraining both juridically and legally-formal up to its social aspects. However, the regional borders that have previously been determined are now open to modifications over time. The objectives of this research are :1) analyse the multitemporal maps as the source of geographical names dynamic inside an area; 2 ) interpret data of dynamic geographical names obtained to be the basis of regional boundaries alteration. The historical map collection of the Royal Tropical Institute in the Library of Map Leiden University (Maps of Magelang from 1855, 1915, 1938, 1940), the topographic map of the U.S. Army Map Service (AMS) (printed in 1945), the Indonesian official topographic maps (Peta Rupabumi Indonesia-RBI) dated 2001, the Google Maps 2018, and the OpenStreetMaps 2018 are altogether utilized in studying the geographical names dynamic of both Magelang Municipality and Magelang Regency. The multitemporal geographical names data are later to be employed to assist the analysis of regional dynamic. We applied the descriptive qualitative method in this research. The existing maps published during the colonialism era and post-Independence Day (1945) can be beneficial to locate the development of regional boundaries and as a resource of multitemporal geographical names. The existence of Magelang Municipality physically has been found since the region belonged to Kedu Residency. On the other hand, the administrative borders were first emerging in a map issued in 1938. The maps from 1855 to 2001 showed that administrative borders of the regions and geographical names examined before were bound to change, mainly on district names. This matter happened due to the proliferation and integration of regions within the Municipality and Regency. Although the borders appeared the same on some of the maps (the 1855 version was similar to the 1915's and from 1938 to 1945 showed the parallel border lines), the maps showed different geographical names. The orthography of geographical names is experiencing changes as well, from using diacritic to using the Perfected Spelling System (Ejaan Yang Disempurnakan-EYD).
\end{abstract}

Keywords: geographical names, regional dynamic, Magelang, Indonesia

\section{Introduction}

Geography is a branch of science which helps bridge between the physical environment study and the cultural situation within the area of interest (Castree, Rogers, \& Sherman, 2005). Based on the Oxford Dictionary, geography studies about physical features of the earth and its atmosphere, and of human activity as it affects and is affected by these, including the distribution of populations and resources and political and economic activities (Oxford University Press, 2018). Holt-Jensen (2009) stated that some people have a vague view of geography scientifically. The fact of geography can be seen from the place's names, location, land use, the topography to other spatial features encountered in map, aerial photography and satellite imagery. Those facts are firmly bound with spatial data, in the form of a map or another visualization. Consequently, geography requires the study of cartography to be the supporting tool for geographical research (Hagget, 2001). One of the cartographic branches is cartography toponymy.

The name is inherent in human life. Personal names, as well as geographical names, have to be the most relevant name-type, along with the name of objects, trademark, the flora' and fauna's names (Hough, 2016). In geography, geographical names or often called as place names or toponyms are examined more frequently compared to other terms (Gammeltoft, 2016). The term of geographical names in Indonesia is interchangeable with nama rupabumi (Badan Informasi Geospasial, 2017). More specifically, this branch of science which learns about geographical names is known as toponymy or toponomastics (Hough, 2016).

Mapping of geographical names is becoming more important, on account of the human who is occupying an area, therefore in that specific location is being given names upon every aspect of geography such as rivers, hills, islands, straits, roads, places, mountains, and the extra 
aspects within one area or the ones spotted on it. Based on the Geospatial Information Act number 4 2011, either a community or individuals who are qualified could make the thematic map. A thematic map-making process employs database from the base map ("Indonesian Acts Number 4 the year 2011 about Geospatial Information," 2011). Then, the geographical name is a mandatory layer that should appear on base maps.

A number of policies related to the geographical name in Indonesia are (Bakosurtanal, 2006): a) upon having several names, another geographical names is considered to be a variant name and recorded inside of national gazetteer; $b$ ) to be able to use the personal name as geographical names if he/.she has been deceased a minimum of 5 years and is considered to hold exceptional merits in local area and/or national; c) to be able to speak foreign languages if it holds a historical value, culture, custom, and/or religion. Geographical names of an area can be altered with the considerations as these (Badan Informasi Geospasial, 2017): 1) is an origin of foreign language and has negative connotation toward national urgency; 2) has been utilized in an area within the same administration level/different location; 3) the changes in status and function; 4) to preserve the local history and culture; 5) upon the urgency of ideology, politic, economic, social and cultural, defence and security, both nationally and internationally; or 6) to give a reward toward a person with exceptional merits for the nation.

Commonly, the name-merging takes place after the process of integrated areas removed to another area. Several aspects that need to be regarded in giving, altering, and erasing names are language, law, international relations, history, anthropology, politic, administration, security and defence of one country. The advantage taken from geographical names includes state sovereignty, disaster management, elections, tourism development, cultural preservation, the reference for administrative border-drawing in public space, and social economy growth.

Geographical names could be used for recognizing the regional dynamic. The regional dynamic seems to be an intense discussion along with the region's autonomy. A region implements their policies within the boundary that has been decided upon; it means that the policies of one region are not allowed to cross lines that have been determined by the constitutions. According to the evaluation of multitemporal maps, the information related to the regional dynamic will be visible.

For instance, a case interconnected with the dynamic of areas in Indonesia is about borders between Magelang Municipality and Magelang Regency. The conflict between the borders emerge as a physical effect of the border lines of such areas are not resolute, meaning there has not been an agreement reached in between two regions at several points. One of the issues behind the disagreement about the borderlines of two regions mostly lies in the possibility of part of the area to carry out such strategical points through two parties. The friction ensues is not merely about the technical problem in the application of juridical boundary out of the constitution on forming an area to a physical site. However, it is very complex and takes an extended period to settle.

The objectives of this research are :

a. Analyse the changes of geographical names using multitemporal maps;

b. Interpret the changes of geographical names as data of regional boundary changes.

\section{The trend of geographical names research}

Geographical names are, by definition, series of words to identify the physical feature as well as the administration of earth, sea, and space objects (Randall, 2001). UNGEGN describes the geographical names as names that are put onto earth's features, consist of residential names, administrative divisions, natural and unnatural features, and open areas that hold a specific local significance (United Nations Group of Experts on Geographical Names, 2006).

Geographical names contain necessary information of location. In addition to that, geographical names also allot to attributive information toward the correlated spatial data (Tent, 2015). With the enlargement of study in association with place names critically (Vuolteenaho \& Berg, 2009), without a doubt, they do not merely act as an information contributor on just the physical background but the anthropological factor as well.

In examining geographical names, a few kinds of approaches can be performed. Research is carried out through qualitative and quantitative manners. A study that engages in geographical names comprises linguistics, history, archeology, anthropology, and geography. Geographical names are the embodiment of humans as a language speaker to respond to the society they reside in. Geographical names can be perceived as a cultural artifact that comes out of the interaction between languages (oral or written) and its surrounding. To know geographical names comprehensively, it is necessary if we know of when the names are worn, of whom, and its motivations (Fellows-Jensen, 2016). It is therefore said that geographical names' research is more effectively performed by a direct visit to the study sites, to converse with locals, and through the medium of a map.

Tent (2015) summarized all of the related researches on geographical names include: (1) the place-naming practice and pattern (both temporal and spatial); (2) the regional distribution for certain geographical types of names, or geographical features; (3) the residential pattern (in both temporal and spatial methods); (4) the geomorphology of an area (by centralizing the attention towards feature types); (5) grammar/geographical names syntaxes; (6) geographical linguistic (a regional distribution for name types); (7) the effect of names on property values. Apriadsa, Cahyono, \& Apriadna (2019) used multitemporal archived maps to to study the effect of the omission of diacritics on the consistency of the present spelling of toponyms and their pronunciation in Indonesia. Meanwhile, Cahyono (2018) used volunteered geographic information to study geographical names in rural area. Spatial approach on geographical names have been carried out by numerous of experts, a few of many are Luo et al. 
(2010), Wang et al. (2014), Qian et al. (2016), and Zeini et al. (2018). Spatial research method on geographical names has been summarized by Wang et al. (2006). Spatial analysis is the process where researchers change the raw spatial data into useful spatial information, and by far it is thoroughly a thought-out creation of spatial information as an additional value on attributive data through options or objective (Longley, Goodchild, Maguire, \& Rhind, 2015). Murayama \& Thapa (2011) states that spatial analysis can be classified into broad and narrow significances. The latter comes off as an analysis method of spatial data. Meanwhile, the broader meaning shows that spatial analysis serves the revelation and clarification of process, structure, begins with the spatial phenomenon occurs on earth. The results are designated in order to aid the spatial decision-taking and functions as a tool to help regional planning and decision making. Longley et al. (2015) say that spatial analysis is the crux of GISSc. It covers the complete information, the manipulation, and the method applied on geographical data to increase those values, to support the decision, and to unravel the pattern and the anomaly that has yet to be clear. In other words, spatial analysis exists to help us with the process of changing the raw data into richer information, scientific discovery, or efficiently capturing a decision.

\section{Area of study and data collection}

This research takes place in Magelang Municipality and Magelang Regency (Figure 1). These two regions adjoin on one another where Magelang is mostly encircled by the Magelang Regency. However, the research focus on the administrative-border change in Magelang. Even though the maps used are partly not covering Magelang Regency administration, they still represent the entirety of Magelang Municipality's most exact condition. Magelang is deliberately selected because of its dynamic, upon its population's growth and the recurring district proliferation.

We used multisource geospatial data such as archived maps in Library of University of Leiden (Kaart Van Het Regentschap Magelang 1855; Magelang en Omstreken 1915; Midden Java Blad 47/XLI 1938; Garnizoenskart Magelang en Omstreken 1940), The first edition of AMS 3 sheet no.47/XLI-A (Magelang), RBI map sheets covering Magelang (Sheet no. 1408-232 (Sendangagung) ; Sheet no. 1408-233 (Kepil); Sheet no. 1408-234 (Mungkid); Sheet no. 1408-241 (Sleman); Sheet no. 1408243 (Muntilan); Sheet no. 1408-244 (Kaliurang); Sheet no. 1408-511 (Kaliangkrik); Sheet no. 1408-512 (Magelang); Sheet no. 1408-521 (Tegalrejo); Sheet no. 1408-522 (Ngablak); Sheet no. 1408-523 (Grabag); Sheet no. 1408524 (Ambarawa)), Maps on Google Maps and also OpenStreetMaps. We did a field survey using GPS, camera, sound recorder, and field survey form.

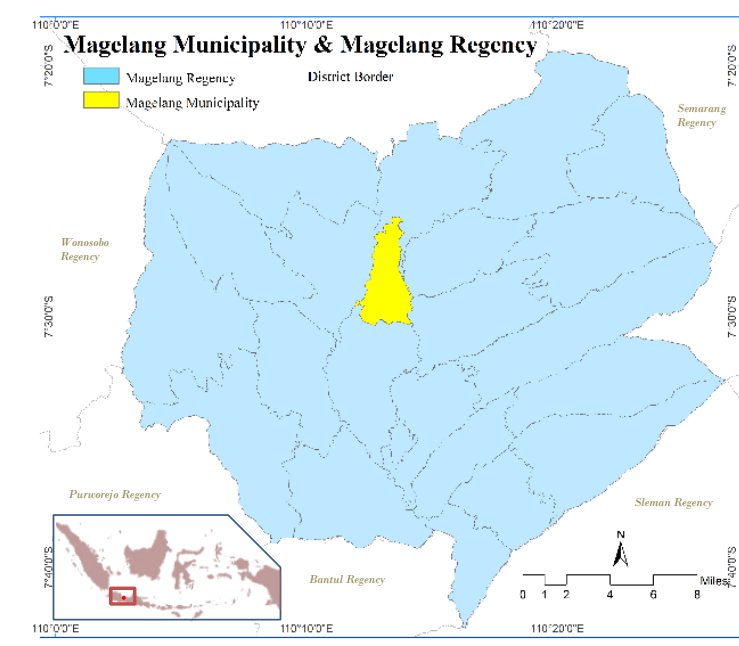

Figure 1. Area of study

\section{Results and Discussions}

\subsection{Magelang from 1855 to 1915}

The Dutch East Indies or now called Indonesia was part of The Netherlands (the Dutch) since 1819. Started from that period there happened a regulation change in Indonesia under the reigning Dutch government. At the same time, the Javanese community transformed into a colonialized community as well as the success of colonial's regulation expansion spread through Sumatra to the eastern Indonesian islands (Gale, 2018). In conjunction with Dutch colonialism, most of the terms were supposed to be written in Latin. Nevertheless, the geographical names in Indonesia were written using Dutch spelling even the maps produced were using Van Ophuijsen's spelling. This orthography was modeled into the style familiar to the Dutch.

Through Kaart van Het Regentschap Magelang or Map of Magelang Regency published in 1855 at the scale of $1: 131.000$, the Regency was divided into seven districts (Figure 2) namely Remameh, Magelang, Bandongan, Ballak, Menoreh, Probolinggo, and Ngassinan. The map was issued with recorded data from Radhen Yoso Dhi Poero. In 1855, the administration of both the city and regency of Magelang was still intact. Sixty years later, the administrative distribution of Magelang Regency was split into seven districts as yet (Figure 3). On the other hand, some of the districts happened to change names. These were them, Menoreh changed to Salaman, Ngassinan to Grabag, Ballak to Tĕgalrědjå, Probolinggo to Moentilan, and Remameh to Salam. The zoning range of each district in 1915 was the same as the 1855's extension. The administrative border lining between Magelang District and other regions appeared to be a river, Kali Ngelo (1855) or Kali Elo (1915) lied on the east side, and Kali Projo (1855) or Kali Prågå (1915) flowed through the west side. Map dated 1915 was another renewal from the 1855's version. The renewal conducted as of the year 1864, under the government of General Staff, was initiated on forming the topography survey department.

Systematic and triangulation Javanese mapping went on from 1850 to 1880. Such mapping was done per 
administration unit or familiarly named as a regency. Java island itself was separated into 23 regencies (Ormeling, 2005), and Magelang belonged to the list. Map dated 1855 contained information of administrative borders, rivers, roads, mountains, and the location of principal government. Meanwhile from a 1915 map, encompassed ample information of additional data of agricultural field deployment, residential, and military infrastructure.

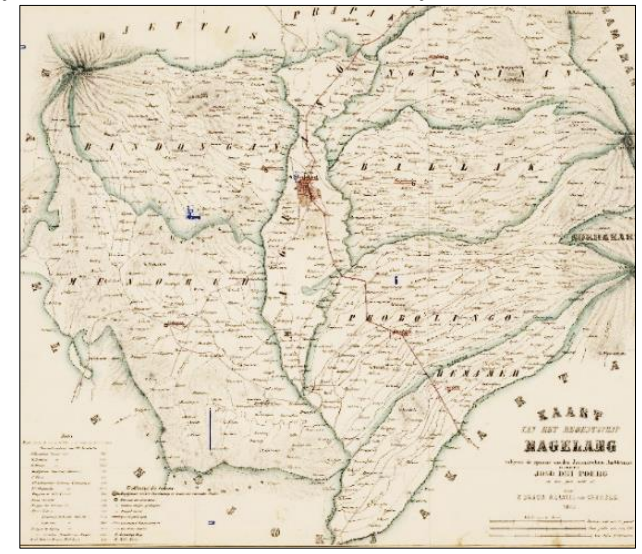

Figure 2. Kaart van Het Regentschap Magelang 1855 (@Map Library of University of Leiden)

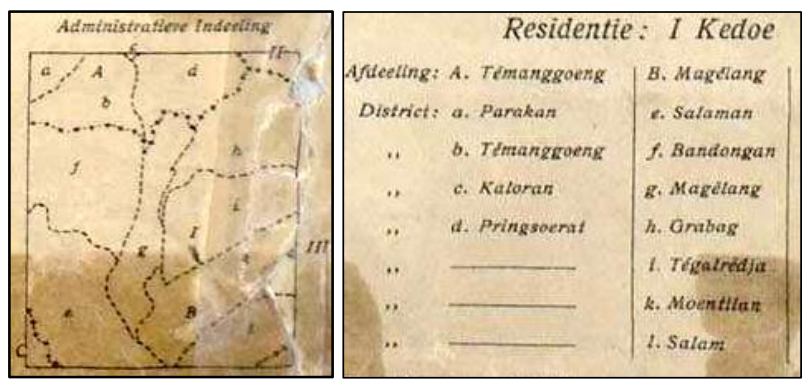

Figure 3. Administrative borderline of Magelang Regency of the year 1915 (@Map Library of University of Leiden)

Along with the previous two maps that employed old orthography in its geographical names writing, the 1915's Magelang en Omstreken map scaled 1:50.000 recorded

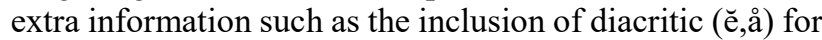
the geographical names. Diacritic taught that a vowel to be pronounced as a whole syllable rather than a diphthong as well as the numeral sequence within the same geographical names. For instance, there were three geographical names "Kĕdoengsari" thus at the beginning or the ending were being given the number of " 1 ", " 2 ", and " 3 ". The geographical name at coordinate X:411272, Y:9171096 was "Kĕdoengsari 1", at coordinate X:410542, Y:9170474 was "Kĕdoengsari 2", "Kĕdoengsari 3" at coordinate $\mathrm{X}: 414304, \mathrm{Y}: 9175982$. The numeral dimension added was smaller compared to its geographical name. These two maps did not possess a coordinate. The Central Mapping Committee issued a regulation to mark a map with a coordinate point from 1905 (Ormeling, 2005). The former coordinates were the ones adjusted to the current location. This subject was carried out by georeferencing a map in 1915 onto RBI map dated back in 2001.

Furthermore, the latest mapping system was designed by J.J.K Enthoven in 1905 using the continuous area scoping system or a map with grid sector alongside the administrative border usage. The chosen map scale was bound to be bigger, 1:50.000, likewise the one from 1915 . Nonetheless, it was unknowable of the reasoning behind 1915's version coordinates nonexistence albeit adopting the newest system.

\subsection{Magelang from 1915 to 1938}

In 1938, diacritic was excluded from the geographical names text but instead was added the coordinates. This fact could be seen through the topographic map produced in The Netherlands in 1938 (Midden Java Blad Map 47/XLI A) (Figure 4). The latest mapping system was designed by J.J.K Enthoven in 1905 using the continuous area scoping system or a map with grid sector alongside the administrative border usage. The chosen map scale was bound to be bigger, read as 1:50.000. Although the mentioned map was to display only four districts (Magelang, Salaman, Tegalrejo, Grabag) (Figure 4), the alteration of the administrative border within 23 years could be seen. Bandongan was a district in the regency during 1915 (Afdeeling B, District f) (Figure 3). Moving to the year of 1938, Bandongan District was changing its name into Magelang District (Regentschap 1, District a) (Figure 4). Magelang District, 1938, was split into three zonings, the northern zone conjoined as Grabag District, the southern zone merged into Tegalredjo District, while the central Magelang remained as Magelang District. The natural border came out as a river, Kali Progo and Kali Elo were administrative borders of Magelang district on the east side.

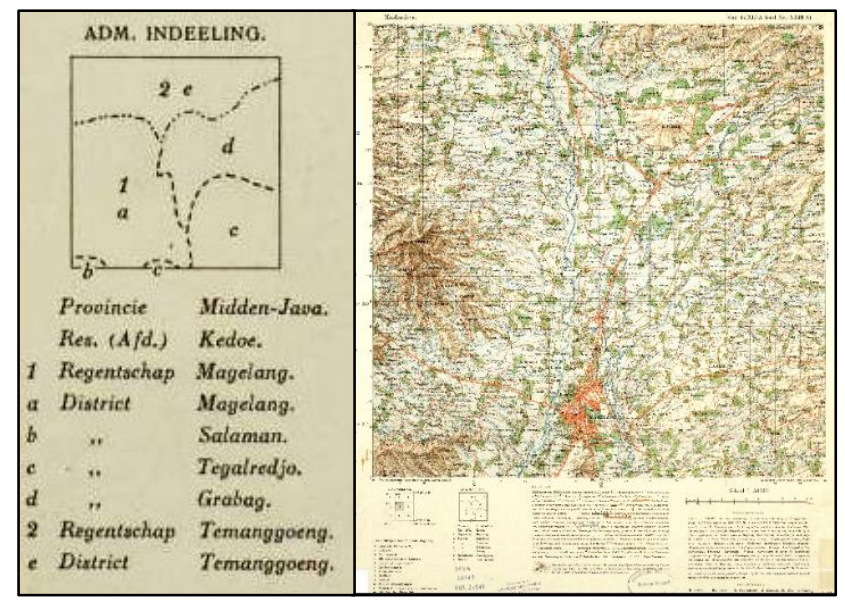

Figure 4. Topographic Map (right) and Administrative Border (left) Midden Java Blad 47/XLI A 1938 (CMap Library of University of Leiden)

The villages in the northern part of Magelang District that merged into Grabag District, namely Samboeng, Setjang, Pajaman, Krintjing, Gintoeng, Kalidjoso, Ngadirodjo, Ngadirodjo, and Ngabean. In the southern part, conjoined Tegalredjo District in 1938 were Mertojoedan, Mantenan, Pending, Klodran, Dejangan, Djapoenan, Soemberredjo, Gedongan, Permitan, Moedjen, Soekoredjo, Kalisari, and Banjoerodjo villages. For the villages in Magelang District from 1915 to 1938 comprised Kedoengsari, Magelang, Kemiriredjo, Redjowinangoen, Pandjang, Tjatjaban, Djoerangombo, and Ngembek. 
Besides the changes of administrative border, there happened as well the changes of geographical names in some villages. 1915, the villages initially named "Ardirědjå" (X:4142020, Y:9181141), "Abean" (X:415701, Y:9183998), and "Embik" (X:413751, $\mathrm{Y}: 9176728)$ to later change into "Ngadirodjo", "Ngabean", and "Ngembek" by 1938. The penning of the same geographical names in 1938's topographic map followed suit by using the numeral sequence stamped in Magelang en Omstreken map toponym (1915) despite the difference in the number order.

\subsection{Magelang from 1940 to 1945}

The 1940's topographic map crafted by The Dutch entitled Garnizoenskart Magelang en Omstreken at the scale 1:50.000 indicated the zero changes on Magelang's administrative border from 1938 to 1940 . The same details were found in Army Map Service (AMS) dated 1945. The map copied out the 1938's Dutch-made map, so there were not any changes regarding Magelang's administrative border started from 1938 to 1945 . For the natural border emerged rivers, Kali Progo and Kali Elo, were to be the administrative lines on the east side.

In early 1940, Japan dethroned The Netherlands and reigned for the remaining times. Dutch was left out with only lesser trope too little to survive from the Japanese's military counterattack and Germany at that. Japan colonized Indonesia during World War II for three years, starting from 1942 to 1945 . With the Netherlands halting their colonialism they might as well have to stop the area mapping. That being said, the topographic maps of Garnizoenskart Magelang en Omstreken made by the Dutch in 1940 and AMS' in 1945 (Figure 5) to show the same administrative borders and features as the version published in 1938 (Figure 4). The 1938's topographic map partook as the very first Atlas established from a tropical country. Despite the declaration of freedom in August 1945, The Netherlands had only acknowledged the sovereignty of Indonesia in 1949 during the Round Table Conference.

The topographic map showing Magelang and its surrounding area that was made by AMS in 1945 did duplicate the Dutch 1938's version was viable as the U.S Department of Data Center, their official diplomacy resource filed out the development of worldwide politic, military, social, and economic from the $20^{\text {th }}$ century, permitted the researchers to disclose such important matters in relation with politics, military, social, and economics happening in a specific country and/or the arising of certain events (Gale, 2018). The charting that was sorted out in the early $20^{\text {th }}$ century to the World War II marked with the ultimate level of plotting operation and the initial introduction of photogrammetry (Ormeling, 2005).
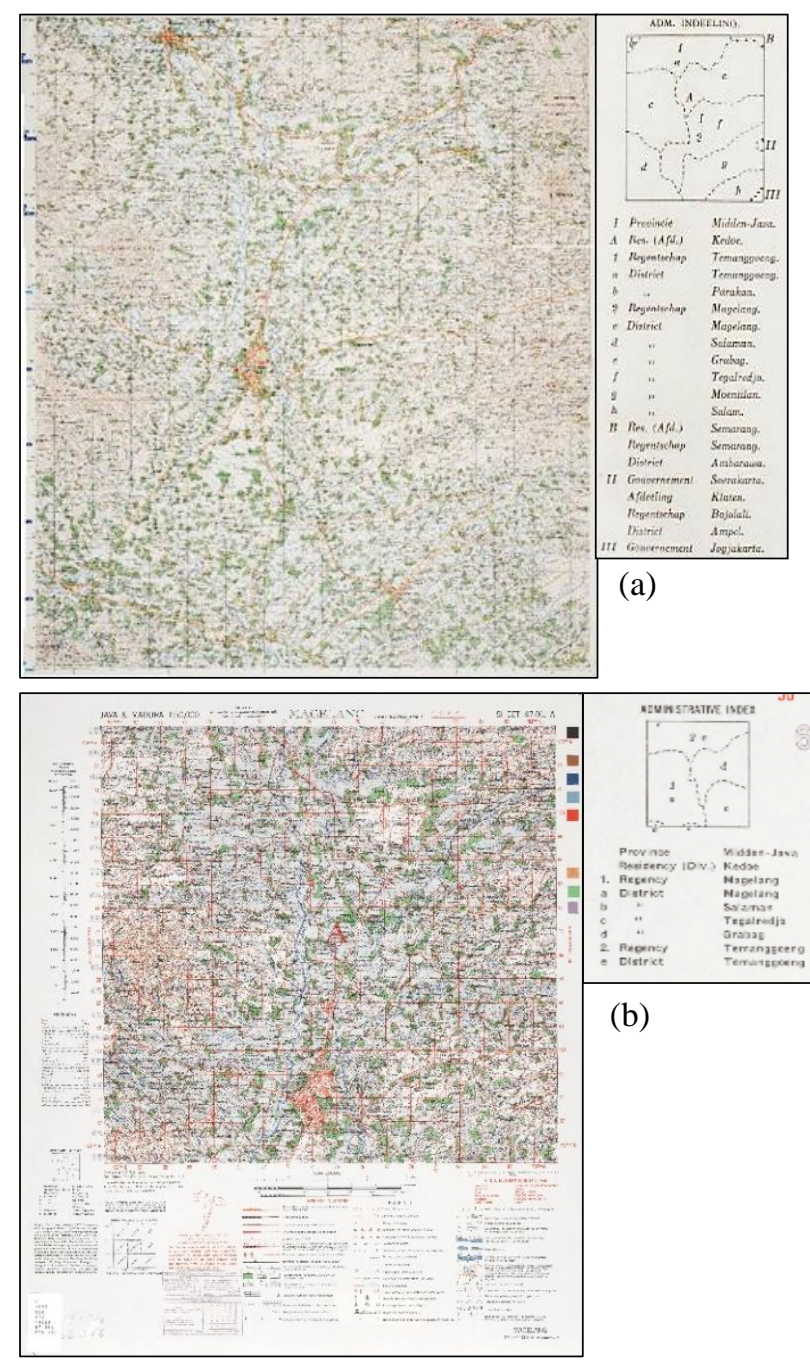

Figure 5. Topographic Map and Administrative Border of Magelang in (a) 1940 and (b) 1945 (CMap Library of University of Leiden)

\subsection{Magelang in 2001}

RBI Maps depicted, at the scale of 1:25.000 published in 2001, Magelang Regency underwent a proliferation of 21 subdistricts comprising Bandongan, Borobudur, Candimulyo, Dukun, Grabag, Kajoran, Kaliangkruk, Mertoyudan, Mungkid, Muntilan, Ngablak, Ngluwar, Pakis, Salam, Salaman, Sawangan, Secang, Srumbung, Tegalrejo, Tempuran, and Windusari. Kota Mungkid was the capital of the regency. Administratively, Magelang Municipality was situated outside of the Regency. Magelang Municipality split into two subdistricts, North Magelang and South Magelang Districts.

The RBI Maps were not composed in old orthography. Instead it had been revised with the perfected spelling system. In these maps could be spotted the spelling modification of village's geographical names, for example, the village at the coordinate of X:413751, Y:9176728 back in 1943 was named "Ngembek", it then went through a proliferation in 2001, and the name had become "Ngembi Kidul" and "Ngembi Lor". Based on RBI Maps, the same geographical names were found in more than two subjects, yet there was no inclusion of number order on matching 
geographical names similarly happened in the colonial topographical maps.

The administrative borders of Magelang Municipality in 2001 were dissimilar to the zoning range in 1945. Even though the rivers as natural objects adapted to be a marker of the administrative lines, Kali Progo was back to being the west side territory, meanwhile Kali Elo for the east side. The amendments of several villages' administration from Magelang District (1945) are listed on Table 1. Magelang district (1945) in 2001 was proliferated into districts Bandongan, Kaliangkrik, Tempuran, Windusari, Magelang Municipality, and Mertoyudan. Karet village established in 1945 was formerly part of Tegalrejo District which later joined Magelang Municipality, located in the coordinate of X:412465, Y:9170649. The southern border of Magelang in 1945 came right through the middle part of Tidar Hill though later in 2001 the prior-mentioned border leaned toward the south precisely to Regional Government Complex and Military Academy. The east border remained in the same position for 56 years from 1945 to 2001.

\begin{tabular}{|c|c|c|c|}
\hline \multicolumn{2}{|c|}{ Village } & \multicolumn{2}{|l|}{ District } \\
\hline The year 1945 & The year 2001 & $\begin{array}{l}\text { The year } \\
1945\end{array}$ & $\begin{array}{ll}\begin{array}{l}\text { The year } \\
2001\end{array} & \end{array}$ \\
\hline Balekerto & Balekerto & Magelang & Kaliangkrik \\
\hline Bandarsedajoe & Bandarsedayu & Magelang & Windusari \\
\hline Bandjarredjo & Banjarrejo & Magelang & Windusari \\
\hline Bandjarsari & Banjarsari & Magelang & Windusari \\
\hline Bandongan & Bandongan & Magelang & Bandongan \\
\hline Banjoewangi & Banyuwangi & Magelang & Bandongan \\
\hline Bekelan & Bekelen & Magelang & Windusari \\
\hline Dalangan & Dalangan & Magelang & Magelang \\
\hline Pandjang & Panjang & Magelang & Magelang \\
\hline Pasangsari & Pasangsari & Magelang & Windusari \\
\hline Djoerang & Jurang & Magelang & Windusari \\
\hline Djoerangombo & Jurangombo & Magelang & Magelang \\
\hline Doempoh & Dumpoh & Magelang & Magelang \\
\hline Gandoesari & Gandusari & Magelang & Bandongan \\
\hline Ganten & Ganten & Magelang & Magelang \\
\hline Genito & Genito & Magelang & Windusari \\
\hline Goenoengsari & Gunungsari & Magelang & Windusari \\
\hline Kalegen & Kalegen & Magelang & Bandongan \\
\hline Kalidjoso & Kalijoso & Magelang & Windusari \\
\hline Kalikebo & Kalikebo & Magelang & Windusari \\
\hline Kantji & Kanci & Magelang & Bandongan \\
\hline Kebonagoeng & Kebonagung & Magelang & Bandongan \\
\hline Kebonlegi & Kebonlegi & Magelang & Kaliangkrik \\
\hline Kedoengsari & Kedungsari & Magelang & Magelang \\
\hline Kembangkoening & Kembangkuning & Magelang & Windusari \\
\hline Gintoeng & Gintung & Magelang & Magelang \\
\hline Kemiriredjo & Kemirirejo & Magelang & Magelang \\
\hline Kentengsari & Kentengsari & Magelang & Windusari \\
\hline Kiringan & Kiringan & Magelang & Windusari \\
\hline Kramat & Kramat & Magelang & Magelang \\
\hline Magelang & Magelang & Magelang & Magelang \\
\hline Magersari & Magersari & Magelang & Magelang \\
\hline Mangoensari & Mangunsari & Magelang & Windusari \\
\hline Windoesari & Windusari & Magelang & Windusari \\
\hline Ngaglik & Ngaglik & Magelang & Tempuran \\
\hline Ngembek & Ngembek & Magelang & Magelang \\
\hline Ngemplak & Ngemplak & Magelang & Windusari \\
\hline Tjandisari & Candisari & Magelang & Windusari \\
\hline Tjatjaban & Cacaban & Magelang & Magelang \\
\hline Tidar & Tidar & Magelang & Magelang \\
\hline
\end{tabular}

\begin{tabular}{|l|l|l|l|}
\hline \multicolumn{2}{|c|}{ Village } & \multicolumn{2}{l|}{ District } \\
\hline The year 1945 & The year 2001 & $\begin{array}{l}\text { The year } \\
1945\end{array}$ & $\begin{array}{l}\text { The year } \\
2001\end{array}$ \\
\hline Tidarwaroeng & Tidarwarung & Magelang & Magelang \\
Redjosari & Rejosari & Magelang & Bandongan \\
Redjowinangoen & Rejowinangun & Magelang & Magelang \\
Salamkantji & Salamkanci & Magelang & Bandongan \\
Sanggrahan & Sanggrahan & Magelang & Magelang \\
Semen & Semen & Magelang & Windusari \\
Sidoredjo & Sidorejo & Magelang & Bandongan \\
Soekosari & Sukosari & Magelang & Bandongan \\
Toegoeran & Tuguran & Magelang & Magelang \\
Tonobojo & Tonoboyo & Magelang & Bandongan \\
Trasan & Trasan & Magelang & Bandongan \\
Troeman & Truman & Magelang & Bandongan \\
\hline
\end{tabular}

Table 1. The proliferation of Magelang District from 1945 to 2001

\subsection{Magelang in 2007}

Both Magelang Municipality and Magelang Regency did not encounter any changes on the administrative border through the regulation of Magelang Municipality number 7 of 2005; the region proliferated its subdistricts and urban villages. Magelang Municipality originally consisted of 2 subdistricts and 14 urban villages, after the proliferation it expanded into three subdistricts comprising subdistrict of North Magelang, Central Magelang, and South Magelang, as well as the 17 urban villages.

\subsection{Magelang in 2018}

By utilizing Open Street Map (OSM) and Google Maps, two web-based applications that are capable of creating maps with the characteristic of open source, the society can exploit them by accessing and/or adding geographical data, specifically the geographical names. Started from 2007 to current days, the changes in the territory of both the city and the regency of Magelang were not clearly visible. On Google Maps, the geographical names data served are not as detailed as the ones on topography maps or the RBI maps. The subdistrict geographical names in specific scales can only be presented through certain areas that are relatively easier on the access and frequently visited (Figure 6). Muntilan, Mungkid, Mertoyudan, Magelang, and Secang are regions which can be come across upon a trip from Yogyakarta to Semarang. The administrative borders and geographical names information are absent, as the challenge arises on differentiating the village, to the subdistrict, to the town, even the regency. OSM is otherwise pretty distinctive with the information where geographical names can be decided upon. On the other hand, the writing of geographical names is categorized through knowledge and the accuracy on documenting the areas conducted by the surveyors. As the chance of inaccuracy on noting down geographical names is seemingly significant. Shown in Figure 7 where "Kedungsari" is supposed to be located at the coordinate of $\mathrm{X}: 414304, \mathrm{Y}: 9175982$ instead of $\mathrm{X}: 415765, \mathrm{Y}: 9173389$ that is likely recorded on OSM. 


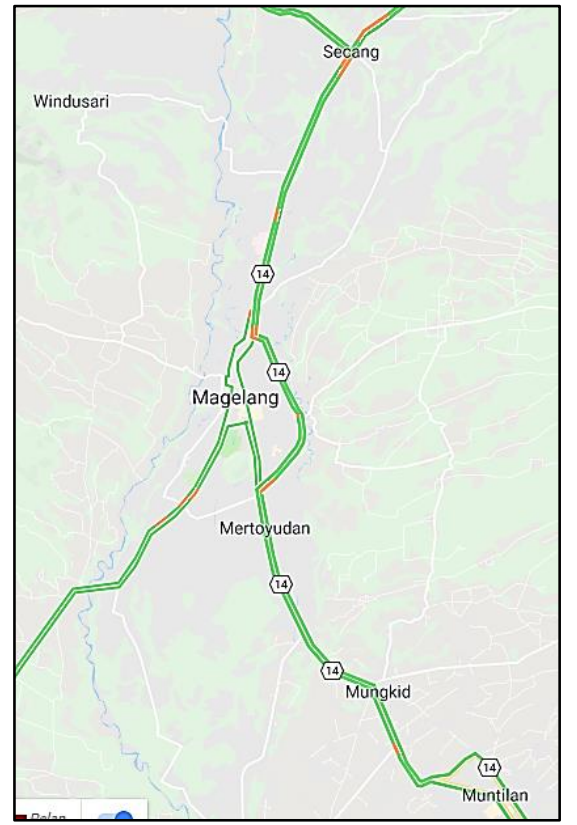

Figure 6. Administrative Geographical names of Municipality and Regency of Magelang on GoogleMaps (ㄷ GoogleMaps, 2019)

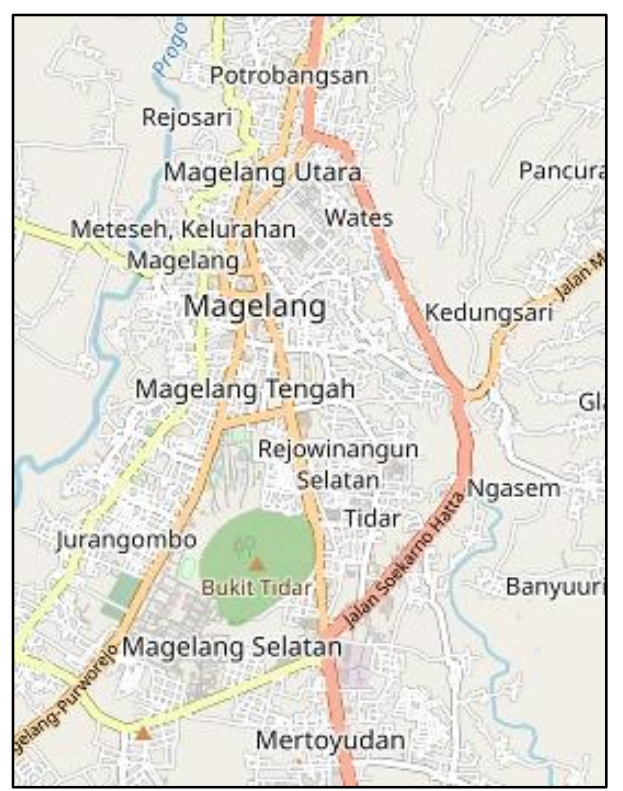

Figure 7. Administrative geographical names of Municipality and Regency of Magelang on OSM (@ OpenStreetMaps,2019)

\section{Conclusions}

Based on this research, we could conclude that: 1) the existing maps, both colonial and post-colonial version maps, can be benefited as a resourceful data of multitemporal geographical names; 2) the growth of regions territory can be tracked from the data of border's progression served on maps; 3) by tracing paths through the maps, the existence of Magelang Municipality in a physical form (the urban constructions) had been borne since it belonged to Kedu Residency. Conversely, Magelang Municipality administratively turned up on maps starting 1938; 4) some of the geographical names came across the changes impacted from the proliferation and integration of regions within parts of Municipality and Regency of Magelang.

\section{Acknowledgements}

This research is funded by the Faculty of Geography, Universitas Gadjah Mada Year 2018 and also a preliminary study of Ari Cahyono's dissertation part. I would like to express gratitude to all the parties involved in the making of this research. We would like to thank the Leiden University Library for the opportunity and permission to access their collection of maps. To the friends at Geospatial Information Agency, particularly to Aji Putra Perdana and Albina Apriadsa, I am grateful for the assistance given to obtain the spatial data related to Magelang Municipality and Magelang Regency. We deliver our sincere gratitude to the colleagues at the Department of Geographical Information Science, specifically to the Cartography Laboratory, thank you for the monthly discussion. Finally, I wish to thank the Local Committee of International Cartographic Conference 2019 and Universitas Gadjah Mada that have considered me with the Travel Grant to present this paper in Tokyo, Japan. Our appreciation to ICA-IGU commission on toponymy, Prof.Hartono, Dr.Bowo Susilo \& Dr. Niken Wirasanti for motivating us to do geographical names research.

\section{References}

Apriadsa, A., Cahyono, A., \& Apriadna, R. (2019). The importance of diacritic on Dutch historical map toponyms in Java, Aceh and Nias. In M. Storms, M. Cams, I. J. Demhardt, \& F. Ormeling (Eds.), Mapping Asia: Cartographic Encounters Between East and West. Champ, Switzerland: Springer International Publishing AG.

Badan Informasi Geospasial. (2017). Peraturan Badan Informasi Geospasial Nomor 6 Tahun 2017 tentang Penyelenggaraan Pembakuan Nama Rupabumi.

Bakosurtanal. (2006). Prinsip, kebijakan dan prosedur pembakuan nama rupabumi. Bogor: Bakosurtanal.

Cahyono, A. (2018). Studi nama geografi melalui layanan pemetaan urundaya di Desa Giripurwo, Purwosari, Gunungkidul D.I. Yogyakarta. Spatial, 18, 105-114.

Castree, N., Rogers, A., \& Sherman, D. (Eds.). (2005). Questioning Geography: Fundamental Debates. Oxford, UK: Blackwell Publishing.

Fellows-Jensen, G. (2016). Names and History. In C. Hough (Ed.), The Oxford Handbook of Names and Naming. Oxford, UK: Oxford University Press.

Gale. (2018). European Colonialism in the Early 20Th Century: Colonialism and Nationalism in the Dutch East Indies, 1910-1930. Retrieved September 20, 2018, from https://www.gale.com/intl/c/europeancolonialism-in-the-early-20th-century-colonialismand-nationalism-in-the-dutch-east-indies-1910-1930

Gammeltoft, P. (2016). Names and Geography. In C. Hough (Ed.), The Oxford Handbook of Names and Naming. Oxford, UK: Oxford University Press. 
Hagget, P. (2001). Geography - A Global Synthesis. New York, United States: Prentice Hall.

Holt-Jensen, A. (2009). Geography: History and Concepts. London, UK: SAGE Publications.

Hough, C. (2016). Introduction. In C. Hough (Ed.), The Oxford Handbook of Names and Naming. Oxford, UK: Oxford University Press.

Indonesian Acts Number 4 the year 2011 about Geospatial Information

Longley, P. A., Goodchild, M. F., Maguire, D. J., \& Rhind, D. W. (2015). Geographic Information Science and Systems (4th ed.). New Jersey, United States: John Wiley \& Sons.

Murayama, Y., \& Thapa, R. B. (2011). Spatial Analysis: Evolution, Methods, and Applications. In Y. Murayama \& R. B. Thapa (Eds.), Spatial Analysis and Modeling in Geographical Transformation Process : GIS-based Applications. Heidelberg, Germany: Springer.

Ormeling, F. (2005). Colonial Cartography of the Netherlands East Indies 1816-1942. In The 22nd International Cartographic Conference. Coruna, Spain.

Oxford University Press. (2018). Geography. Retrieved April 6, 2018, from https://en.oxforddictionaries.com/definition/geograph $\mathrm{y}$

Randall, R. R. (2001). Place Names : How They Define the World and More. Maryland, United States: Scarecrow Press.

Tent, J. (2015). Approaches to research in toponymy. Names, 63, 65-74.

United Nations Group of Experts on Geographical Names. (2006). Manual for the national standardization of geographical names. New York, United States: United Nations Publication.

Vuolteenaho, J., \& Berg, L. D. (2009). Towards critical toponymies. In J. Vuolteenaho \& L. D. Berg (Eds.), Critical Toponymies: The Contested Politics of Place Naming. New York, United States: Routledge. 